\title{
Pengaruh mandi uap terhadap tekanan darah pada wanita dewasa normal
}

\author{
${ }^{1}$ Stacey Polii \\ ${ }^{2}$ Jimmy F. Rumampuk \\ Fransiska Lintong
}

\author{
${ }^{1}$ Kandidat Skripsi Fakultas Kedokteran Universitas Sam Ratulangi \\ ${ }^{2}$ Bagian Ilmu Fisika Fakultas KedokteranUniversitas Sam Ratulangi \\ Email: staceypolii12012@gmail.com
}

\begin{abstract}
Physics apply heat energy use in the fields of medicine. At present, many people enjoy a steam bath as a means of muscle relaxation, but the steam bath therapy is often not recommended for patients with hypertension. The steam bath is said to be dangerous for people with hypertension, but what exactly happened to the blood pressure during the steam bath. The purpose of this study is to determine whether the steam shower effect on blood pressure normal adult women. The draft of this study was cross sectional analytical survey (cross-sectional) or only done once a certain time. The research location is housed in Tikala Shiatu Spa, Tikala Ares, Wenang. Samples were taken from women aged 20-25 years were 40 people with normal healthy state. Results showed highly significant differences in systolic blood pressure 15 minutes into the value $(\mathrm{p}=0.001)$ and systolic blood pressure to 20 minutes $(p=0.000)$. Diastolic blood pressure results show a very significant difference that in the 15th minute $(p=0.002)$ and 20th minute $(p=0.001)$. Conclusion: There is a significant rise in systolic and diastolic blood pressure while doing 20 minutes steam bath
\end{abstract}

Keywords: blood pressure, steam.

\begin{abstract}
Abstrak: Ilmu fisika menerapkan penggunaan energi panas dalam bidang kedokteran. Pada saat sekarang, banyak orang menikmati mandi uap sebagai sarana relaksasi otot, namun terapi mandi uap sering tidak dianjurkan untuk penderita hipertensi. Mandi uap dikatakan dapat berbahaya untuk penderita hipertensi, namun apa sebenarnya yang terjadi terhadap tekanan darah selama mandi uap ?. Tujuan dari penelitian ini yaitu untuk mengetahui apakah mandi uap berpengaruh terhadap tekanan darah wanita dewasa normal. Rancangan dari penelitian ini adalah survey analitik secara potong lintang (cross sectional) atau hanya dilakukan sekali dalam waktu tertentu. Lokasi penelitian bertempat di Tikala Shiatu Spa, Tikala Ares, Wenang. Sampel penelitian diambil dari wanita usia 20-25 tahun berjumlah 40 orang dengan keadaan sehat dan normal. Hasil Penelitian menunjukkan perbedaan yang sangat bermakna pada tekanan darah sistolik menit ke 15 dengan nilai $(p=0,001)$ dan tekanan darah sistolik menit ke $20(p=0,000)$. Hasil tekanan darah diastolic menunjukkan perbedaan yang sangat bermakna yakni pada menit ke $15(p=0,002)$ dan menit ke $20(p=0,001)$. Simpulan: Terdapat peningkatan tekanan darah sistolik dan diastolik yang signifikan saat mandi uap selama 20 menit.
\end{abstract}

Kata kunci: tekanan darah, mandi uap

Mandi uap atau sauna telah digunakan selama berabad-abad di berbagai belahan dunia. Zaman dahulu mandi uap sudah populer di kalangan orang Yunani kuno kemudian mandi uap disebut "Sudatorium" setelah diadopsi oleh bangsa Romawi dan menyebar hingga digunakan oleh Kerajaan Romawi. Negara Turki, "Hamam” atau 
mandi uap telah ada sejak beratus-ratus tahun yang lalu dan menggunakan nama "Turkish Bath". Kemudian Mandi uap berkembang ke daerah Rusia dan dikenal dengan "Banja". Sementara itu di Eropa, mandi uap sudah berkembang dan memiliki masalah mengenai pengaturan temperatur. Pada zaman modern ini, mandi uap hampir dapat dinikmati dimana saja dengan harga yang terjangkau. ${ }^{1}$

Tempat spa, shiatsu dan pemandian air panas tradisional sudah banyak tersebar di Indonesia termasuk di Manado. Metode mandi uap sendiri sebagai penyegar atau untuk merelaksasi otot, tetapi manfaat pasti dalam kesehatan belum diketahui. Mandi uap dilaksanakan pada ruangan khusus dimana sisi sisi ruangannya mengeluarkan uap panas yang beroperasi antara suhu $43^{\circ} \mathrm{C}$ dan $46^{\circ} \mathrm{C}$. Kabut dalam ruangan mandi uap harus berada dalam ruangan terus menerus secara permanen. Hal ini tentunya membutuhkan generator uap yang efisien, sistem kontrol yang baik dan ruang uap kabin yang ketat untuk mencegah uap keluar dari ruangan dan merusak area sekitarnya. ${ }^{1}$

Universitas Munich's Institut Kedokteran Klimatologi di antara tahun 1983 dan 1986, serangkaian uji coba tentang efek dari mandi uap pada tubuh manusia telah dilakukan. Hasil penelitian menjelaskan bahwa mandi uap berguna untuk yang memerlukan kelembapan tetapi tidak dianjurkan bagi penderita penyakit jantung. Uap dalam sauna secara tidak langsung berpengaruh terhadap sistem autonomi dan endokrin serta keseimbangan elektrolit. Hubungan antara adrenalin dan steroid dalam darah juga merupakan hal penting yang berpengaruh dalam

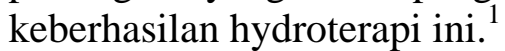

Pada bidang kedokteran, mandi uap digunakan dalam pengobatan dengan memanfaatkan energi panas dari uap. Mandi uap mengambil dasar fisik antara kedua benda dengan mengadopsi metoda konduksi. Apabila terdapat perbedaan temperatur antara kedua benda maka secara konduksi panas akan ditransfer yaitu dari benda yang lebih panas ke benda yang lebih dingin. ${ }^{2}$ Energi panas dalam ruang sauna ditransfer terhadap ke dalam tubuh pengguna yang memiliki suhu badan lebih dingin. Energi panas yang ditransfer ke dalam tubuh inilah yang berpengaruh terhadap sistem peredaran darah, nadi serta sitem endokrin dan respirasi.

Penggunaan ruangan mandi uap biasanya berkisar antara 5-20 menit, tentunya bergantung pada ketahanan tubuh seseorang. Terapi panas masuk ke dalam tubuh dan meningkatkan aliran darah, melebarkan pembuluh darah, meningkatkan oksigen dan pengiriman nutrisi ke jaringan lokal, dan mengurangi kekakuan sendi dengan cara meningkatkan elastisitas otot. ${ }^{3}$ Mandi uap sendiri memiliki beberapa manfaat seperti meningkatkan sirkulasi darah, mengobati gangguan tidur, dan merelaksasi otot. ${ }^{1}$

\section{METODE PENELITIAN}

Penelitian dilakukan pada bulan November-Desember 2015 bertempat di Tikala Shiatsu, JL. Kembang, Sario, Manado, berdasarkan survei analitik dengan menggunakan desain penelitian studi potong lintang atau cross sectional. Populasi penelitian adalah pengguna terapi panas mandi uap/ sauna dengan sampel penelitian sebanyak 40 subjek wanita dewasa usia 20-25 tahun yang sehat fisik. Subjek penelitian berumur 20-25 tahun serta setuju dan bersedia menandatangani Informed Consent. Subjek dalam keadaan sehat jasmani dan rohani, tidak menderita sakit kronik dan akut, serta dalam keadaan bugar. Subjek diharapkan dapat bekerja sama dan berkomunikasi dengan peneliti. Alat dan bahan penelitian seperti lembar Informed Consent, sfigmomanometri aneroid, stetoskop, lembar pencacatan data penelitian, jam analog, alat tulis, dan laptop. Peneliti mengukur tekanan darah dengan menggunakan sfigmomanometer aneroid pada brachialis sinistra di atas arteri brachialis sebelum mandi uap , saat 10 menit mandi uap, 15 menit mandi uap dan 20 menit mandi uap. Analisis data menggunakan Uji T Berpasangan ( paired T-test ) . 


\section{HASIL PENELITIAN}

Tekanan darah subjek saat 10 menit mandi uap, 15 menit mandi uap dan 20 menit mandi uap mengalami perbedaan yang signifikan.

Tabel 1. Data Hasil Pengukuran Tekanan Darah Sistolik saat Mandi Uap.

\begin{tabular}{lllll}
\hline & TDS 0 & TDS & TDS & TDS \\
& & 10 & 15 & 20 \\
\hline $\mathrm{N}$ & 40 & 40 & 40 & 40 \\
Min & 90 & 100 & 100 & 100 \\
Max & 140 & 150 & 140 & 140 \\
Median & 110,00 & 110,00 & 110,00 & 120,00 \\
Mean & 110,50 & 111,50 & 115,25 & 116,75 \\
SD & 9.323 & 9,487 & 8,469 & 8,590 \\
\hline
\end{tabular}

Penelitian ini juga membandingkan tekanan darah sistolik sebelum mandi uap dan saat mandi uap setiap 10, 15, dan 20 menit.

Tabel 2. Data Hasil Uji Perbedaan TDS awal dan TDS akhir.

\begin{tabular}{cccc}
\hline TDS & TDS & $\mathrm{t}$ & Nilai p \\
Awal & Akhir & & \\
\hline Menit 0 & Menit 10 & $-0,703$ & 0,243 \\
Menit 0 & Menit 15 & -3.318 & 0,001 \\
Menit 0 & Menit 20 & $-3,838$ & 0,000 \\
\hline
\end{tabular}

Pada Tabel 2 hasil uji pengaruh mandi uap terhadap TDS dengan uji t berpasangan diperoleh hasil sebagai berikut:

1. Tidak terdapat perbedaan yang bermakna TDS sebelum dan sesudah mandi uap pada menit ke-10 ( $\mathrm{p}=0,243)$.

2.Terdapat perbedaan yang sangat bermakna TDS sebelum dan sesudah mandi uap pada menit ke-15 ( $\mathrm{p}=0,001)$.

3.Terdapat perbedaan yang sangat bermakna TDS sebelum dan sesudah mandi uap pada menit ke-20 ( $<<0,001)$.

Pada Tabel 3 dapat dilihat perbandingan rata-rata nilai tekanan darah diastolik sebelum mandi uap dan saat mandi uap berlangsung.
Tabel 3. Data Hasil Pengukuran Tekanan Darah Diastolik saat Mandi Uap.

\begin{tabular}{lcccc}
\hline & TDD & TDD & TDD & TDD \\
& 0 & 10 & 15 & 20 \\
\hline $\mathrm{N}$ & 40 & 40 & 40 & 40 \\
Minimum & 60 & 70 & 70 & 60 \\
Maximum & 100 & 100 & 100 & 100 \\
Median & 80,00 & 80,00 & 80,00 & 80,00 \\
Mean & 76,25 & 77,75 & 79,50 & 80,25 \\
Std. & 7,403 & 6,597 & 5,970 & 6,597 \\
Deviation & & & & \\
\hline
\end{tabular}

Tabel 4. Data Hasil Uji Perbedaan TDD awal dan TDD akhir.

\begin{tabular}{cccc}
\hline TDD & TDD & t & Nilai p \\
Awal & Akhir & & \\
\hline Menit 0 & Menit 10 & $-1,433$ & 0,080 \\
Menit 0 & Menit 15 & $-2,962$ & 0,002 \\
Menit 0 & Menit 20 & $-3,122$ & 0,001 \\
\hline
\end{tabular}

Pada Tabel 4 hasil uji pengaruh mandi uap terhadap TDS dengan uji $\mathrm{t}$ berpasangan diperoleh hasil sebagai berikut:

1. Tidak terdapat perbedaan yang bermakna TDD sebelum dan sesudah mandi uap pada menit ke-10 ( $\mathrm{p}=$ 0,080).

2. Terdapat perbedaan yang sangat bermakna TDD sebelum dan sesudah mandi uap pada menit ke-15 ( $\mathrm{p}=$ 0,002).

3. Terdapat perbedaan yang sangat bermakna TDD sebelum dan sesudah mandi uap pada menit ke-20 ( $\mathrm{p}=$ 0,001).

\section{BAHASAN}

Mandi uap selama ini diyakini memiliki efek untuk badan agar rileks, tetap cantik, memperlancar peredaran darah, serta untuk mengurangi berat badan. Namun kerap didengar bahwa mandi uap tidak disarankan kepada mereka yang berpenyakit jantung, atau hipertensi dikarenakan dapat mengancam jiwa seketika. Selama mandi uap berlangsung, suhu tubuh saat masuk ke dalam ruangan tentunya lebih rendah dibandingkan dengan suhu ruangan sauna. Dengan metode konduksi, panas akan berpindah ke daerah 
yang memiliki suhu lebih rendah, sehingga panas dalam ruangan akan berpindah dan mempengaruhi suhu tubuh sampel. Saat tubuh sedang dalam ruangan yang lebih dingin dan suhu tubuh lebih panas, tentunya tubuh akan mengeluarkan panas dan suhu tubuh akan turun, tubuh kemudian melakukan kontrol homeostatis sehingga panas yang keluar dari dalam tubuh tetap sebanding dengan panas yang diproduksi dalam tubuh, menyebabkan suhu tubuh tetap konstan dan tidak berkurang. Semakin lama seseorang berada dalam ruangan yang suhunya semakin rendah suhu tubuh juga akan berangsur- angsur turun. Jika tubuh secara terus menerus berada dalam ruangan sauna yang panas, maka tubuh akan berkeringat dan temperature tubuh akan menigkat. ${ }^{4}$

Semakin panas suhu ruangan, maka aliran darah semakin banyak mengarah ke permukaan kulit. Pada permukaan kulit akan berkeringat dikarenakan, darah membawa panas dari dalam tubuh untuk dikeluarkan ke lingkungan melalui kulit. ${ }^{4}$ Saat suhu tubuh meningkat dikarenakan ruangan sauna yang tetap panas dan semakin panas, maka jantung akan berkontraksi lebih cepat dan denyut jantung meningkat. Maka suhu ruangan yang panas mempengaruhi jantung sampel sehingga berdetak lebih cepat juga berkontraksi lebih cepat sehingga heart rate meningkat. ${ }^{5}$

Ketika denyut jantung meningkat maka jantung bertindak seperti pompa dan menyebabkan tekanan darah meningkat. Tekanan darah sistolik yang meningkat juga bisa didapatkan karena suhu tubuh yang tinggi, dalam hal mandi uap ketika sudah semakin lama mandi uap saat 15-20 menit, tubuh telah mengambil sebagian besar panas dari ruangan luar sehingga menyebabkan tubuh serperti sedang demam dan sistol meningkat. ${ }^{6}$

Jika orang berpenyakit jantung, dengan keadaan jantung yang tidak normal menjalani mandi uap atau sauna dengan waktu yang lama, maka dapat berakibat fatal. Saat mandi uap jantung akan berkontraksi lebih cepat sehingga seperti seorang yang sedang berlari, jika kondisi jantung tidak sehat dan tidak kuat untuk menahan jantung yang memompa begitu kencang maka jantung dapat berhenti berdetak dan seketika akan terjadi kematian. $^{7}$ Ketika jantung memompa begitu kencang, ventrikel bekerja lebih cepat dan meningkatkan tekanan darah , hal ini juga berbahaya untuk pada penderita penyakit hipertensi yang tidak terkontrol. ${ }^{8}$

Selama mandi uap, ada juga yang mengalami tekanan darah turun, hal ini bisa disebabkan karena terjadinya dehidrasi. ${ }^{8}$ Saat mandi uap ada yang tidak mengeluarkan keringat yang banyak, hal ini menyebabkan tekanan darah juga sangat meningkat disebabkan panas yang terkumpul dalam tubuh tidak dikeluarkan secara maksimal lewat kulit. ${ }^{7}$ Saat mandi uap, saraf simpatik juga mengambil bagian dalam meningkat denyut jantung. Bagi para penikmat mandi uap sering merasakan sesak nafas, ini diakibatkan oleh tubuh yang belum terbiasa dengan aktifitas dalam suhu tinggi dengan jantung yang memompa lebih cepat, menyebabkan dyspnea saat mandi uap. Jika sudah terbiasa maka tidak akan takut dengan susah bernafas dalam ruangan mandi uap. ${ }^{9}$

Bagi penderita penyakit jantung dan hipertensi yang ingin menikmati mandi uap sebaiknya menghubungi dokter terlebih dahulu untuk konsultasi. Pengaruh lamanya mandi uap sebaiknya diperhitungkan dikarenakan kenaikkan tekanan darah dapat terjadi diatas 10 menit mandi uap. Untuk ibu hamil juga disarankan untuk tidak mandi uap dengan kemauan sendiri, harus konsultasi dengan dokter. Jika tidak dikonsultasikan, maka beresiko untuk bayi mengalami cacat saraf dan membahayakan janin. Dalam melakukan sauna, minumlah banyak air terlebih dahulu, mandi yang bersih untuk membersihkan minyak di tubuh, serta jangan melakukan mandi uap lebih dari 20 menit untuk orang normal, ini untuk menghindari hal- hal yang tidak diinginkan. ${ }^{10}$

Berdasarkan hasil pada penelitian ini, didapatkan 33 orang dengan peningkatan tekanan darah, dan 7 orang dengan tekanan darah menurun. Berdasarkan hasil uji $\mathrm{T}$ 
berpasangan didapatkan nilai $\mathrm{p}=0.001$ $(\mathrm{p}<0.05)$ pada menit ke 15 dan $\mathrm{p}=0.000$ $(\mathrm{p}<0.05)$ pada menit ke 20 tekanan darah sistolik. Sementara pada tekanan darah diastolik $\mathrm{p}=0.002(\mathrm{p}<0.05)$ pada menit ke 15 , dan $\mathrm{p}=0.001 \quad(\mathrm{p}<0.05)$ pada menit ke 20 .

\section{SIMPULAN DAN SARAN}

Berdasarkan hasil penelitian yang telah dilakukan, maka dapat disimpulkan sebagai berikut:

1. Nilai tekanan darah yang didapatkan sebelum mandi uap pada subjek penelitian masih dalam batas normal tekanan darah.

2. Tekanan darah sistolik dan diastolik sebelum mandi uap dan sesudah mandi uap mengalami perubahan saat menit ke15 dan menit ke-20 dengan terjadinya peningkatan tekanan darah pada subjek.

Bagi penderita penyakit jantung dan hipertensi tidak dianjurkan untuk mandi uap.

\section{DAFTAR PUSTAKA}

1. Steam bath [homepage on the internet]. c2015 [updated 2015 Jan 1; cited 2015 Sep 21]. Available from: http//www.sld.cu/galerias/pdf/sitios/r ehabilitacion-bal.

2. Gabriel J.F. Fisika Kedokteran. Jakarta: buku kedokteran EGC, 1996; p.13031.

3. Gatlin CG, Schulmeister L. When medicine is not enough : Nonpharmacologic management of pain. Clinical Journal of Oncology Nursing. In: Salvo GS. Massage
Therapy (5th ed). Missouri: Elsevier, 2007; p. 699-704.

4. Widmaier EP, Raff H, Strang KT. Vander's human physiology:the mechanisms of body function (13th ed.) .New York: Mc Graw Hill, 2014.p.2-19.

5. Ranada VG. A textbook of practical physiology (3rd ed). Yogyakarta: Lokasangraha Press, 2006.p.121-63.

6. Murphy JG, Lloyd MA. Mayo clinic cardiology consive textbook. (3rd ed). New York: Oxford University, 2013;р.3-19.

7. Martini FH, Nath JL, Bartholomew EF. Fundamentals of anatomy \& physiology (10th ed). San Fransisco: Pearson Education Inc, 2012.p.1-25.

8. Sembulingam $K$, Sembulingam $P$. Essensial of medical physiology (6th ed). New Delhi: Jaypee Brothers Medical Publisher, 2012.p.3-42.

9. Stromme SB, Boushel R, Ekblom B, Huikuri H, Tulppo MP, Jones NL. Cardiovascular and respiratory aspects of exercise endurance training. In: Kjaer M, Krogsgaard M, Magnussan P, Engebretsen L, Roos $\mathrm{H}$, Takala Timo, editors. Textbook of sport medicine:basic science and clinical aspects of sports injury and physical activity (1 st ed). Massachusetts: Blackwell Publishing, 2003.p.11-173.

10. Manfaat sehat mandi uap sauna [homepage on the internet]. c2002 [updated 2002 Dec 17; cited 2016 Jan 17]. Available from:

http://ahlisauna.com/index.php/home/ 4-latest-articles/17-sauna-manfaatsehat-mandi-uap. 